\title{
OS ACORDOS NAS AÇÕES DE IMPROBIDADE ADMINISTRATIVA
}

\author{
Flávia Baracho Lotti Campos de Souza* \\ Sérgio Henriques Zandona Freitas ${ }^{* *}$
}

\section{RESUMO:}

$\mathrm{O}$ art. $17, \S 1^{\circ}$ Lei 8.429/92, em sua redação original, vedava acordos, transações ou conciliações nas ações de improbidade administrativa, embora o CPC/15 tenha estabelecido como fundamento processual a busca pela solução consensual de conflitos. A Lei 13.964/19, alterou a Lei 8.429/92 para admitir os acordos de não persecução civil nas ações de improbidade, todavia sem regulamentação. Assim, buscar-se-á, a partir de pesquisa bibliográfica, utilizando-se do método dedutivo e referencial teórico a teoria do ordenamento jurídico de Bobbio, discorrer sobre evolução jurídica-normativa dos ajustes e suas implicâncias, para concluir pela aplicação analógica das diretrizes previstas nas Resoluções do Ministério Público.

PALAVRAS-CHAVE: Improbidade administrativa; Acordos; Pacote anticrime; CPC/15; Lei 8.429/92, alterada pela Lei 13.964/19.

\section{AGREEMENTS IN ADMINISTRATIVE MISCONDUCT ACTIONS}

\begin{abstract}
:
Art. $17, \S 1$ of act $8.429 / 92$, in its original wording, prohibited agreements, transactions or reconciliations in administrative misconduct actions, although $\mathrm{CPC} / 15$ established gone as a procedural basis, the search for consensual settlement of conflicts. Act 13.964/19, amended act 8.429/92 to admit civil non-pursuit agreements in misconductactions, however without regulation. The theory of the legal system of Bobbio will seek, from a bibliographic research, to conclude by analog application of guidelines provided for in the Resolutions of the Public Prosecutor's Office.
\end{abstract}

KEYWORDS: Administrative improbity; Agreements; Anti-crime package; CPC/15; Act 13.964/19, amended act 8.429/92.

\footnotetext{
* Mestranda em Direito pela Universidade FUMEC. Pós-graduada em Direito Processual pela Pontifícia Universidade Católica de Minas Gerais (PUC MINAS). Assessora Judiciária no Tribunal de Justiça do Estado de Minas Gerais (TJMG). E-mail: flaviabaracho@gmail.com. Currículo Lattes: http://lattes.cnpq.br/6974995901549094

${ }^{* *}$ Pós-Doutor em Direito pelo Programa de Pós-Graduação Stricto Sensu em Direito (PPGD) da Universidade do Vale do Rio dos Sinos - UNISINOS (São Leopoldo/RS). Pós-Doutor em Democracia e Direitos Humanos pela Faculdade de Direito da Universidade de Coimbra (Portugal). Doutor, Mestre e Especialista em Direito pela Pontifícia Universidade Católica de Minas Gerais (PUC MINAS). Coordenador do Programa de Pós-Graduação Stricto Sensu em Direito (PPGD) da Universidade FUMEC. Editor Chefe da Revista Jurídica Meritum FUMEC. Professor da Faculdade de Ciências Humanas, Sociais e da Saúde (FCH) da Universidade FUMEC, atuando como docente permanente da Graduação, Especialização e do Programa de Pós-Graduação Stricto Sensu em Direito (PPGD). Assessor Judiciário no Tribunal de Justiça do Estado de Minas Gerais (TJMG). E-mail: sergiohzf@fumec.br. Currículo Lattes: http://lattes.cnpq.br/2720114652322968.
} 


\section{INTRODUÇÃO}

A improbidade administrativa, na esfera cível, por meio do art. $17, \S 1^{\circ}$ da Lei n. $^{\circ}$ 8.429/92 - Lei de Improbidade Administrativa, em sua redação original, vedava, de forma expressa, a transação, o acordo ou a conciliação no curso das ações de improbidade, fundado no princípio da indisponibilidade do interesse público, afastando a possibilidade de realização do compromisso de ajustamento de conduta (BRASIL, 1992), previsto no art. $5^{\circ}, \S 6^{\circ}$ da Lei n. ${ }^{\circ}$ 7.347/85 - Lei de Ação Civil Pública (BRASIL, 1985).

Durante este período foram editadas a caducada MP n. ${ }^{\circ}$ 703/15, a Resolução n. ${ }^{\circ}$ 179, de 26 de julho de 2017 do Conselho Nacional do Ministério Público - CNMP e a Resolução n. ${ }^{\circ}$ 03, de 23 de novembro de 2017, do Conselho Superior do Ministério Público do Estado de Minas Gerais - CSMPMG, que se propuseram a regulamentar e orientar seus membros à realização dos compromissos de ajustamento de conduta nas ações civis públicas, bem como nas hipóteses configuradoras de improbidade administrativa (BRASIL, 2017; MINAS GERAIS, 2017).

Paralelamente, outras normas jurídicas, que compõe o chamado microssistema de combate à corrupção, criaram instrumentos extrajudiciais para a realização de acordos, ainda que a conduta também estivesse tipificada na Lei de Improbidade Administrativa. No âmbito administrativo, há o acordo de leniência, previsto na Lei n. ${ }^{\circ}$ 12.846/13 - Lei Anticorrupção e, na esfera penal, o instituto da colaboração ou delação premiada, regulamentado pela Lei n. ${ }^{\circ}$ 12.850/13 - Lei da Organização Criminosa (BRASIL, 2013).

Em 24 de dezembro de 2019, a Lei n. ${ }^{o}$ 13.964/19 - Pacote Anticrime (BRASIL, 2019) aperfeiçoou a legislação penal e processual penal e trouxe significativas mudanças na esfera administrativa, em especial, na Lei n. ${ }^{\circ} 8.429 / 92$, que alterou o art. $17, \S 1^{\circ}$ para admitir os acordos de não persecução civil nas ações de improbidade administrativa, embora não regulamentado.

Assim, pergunta-se: enquanto não regulamentada por Lei, é possível, a partir de uma aplicação analógica, realizar os acordos judiciais, com base nas Resoluções do Conselho Nacional do Ministério Público e do Conselho Superior do Ministério Público do Estado de Minas Gerais?

Em resumo, este artigo tem como objetivo, a partir de uma pesquisa bibliográfica, utilizando-se do método dedutivo e como referencial teórico a teoria do ordenamento jurídico 
de Norberto Bobbio, apresentar a evolução jurídico-normativa dos acordos nas ações de improbidade administrativa e discorrer sobre a aplicabilidade do novo dispositivo legal, instituído pela Lei n. ${ }^{\circ}$ 13.964/19.

Para tanto, o artigo será estruturado de forma a conceituar o compromisso de ajustamento de conduta; apresentar a evolução normativa dos acordos nas ações de improbidade administrativa, em especial as alterações promovidas pelo Pacote Anticrime; expor sobre a teoria geral do direito, em especial os critérios de supressão das lacunas legislativas e, ao final, concluir sobre a possibilidade de aplicação das Resoluções do Conselho Nacional do Ministério Público (CNMP) e do Conselho Superior do Ministério Público de Minas Gerais (CSMPMG).

\section{O COMPROMISSO DE AJUSTAMENTO DE CONDUTA}

Muito antes do Código de Processo Civil de 2015 - CPC/15 que elevou a conciliação, a mediação e outros métodos de solução consensual de conflitos a fundamento da nova sistemática processual brasileira (BRASIL, 2015), o compromisso de ajustamento de conduta é utilizado como instrumento de proteção dos direitos coletivos, a despeito do processo judicial, visando a satisfação mais célere e eficaz dos interesses das partes.

O compromisso de ajustamento de conduta ou termo de ajustamento de conduta TAC já tinha previsão legal com o art. 211 da Lei n. ${ }^{\circ}$ 8.069/90 - Estatuto da Criança e do Adolescente $^{1}$ e, como precursor, a transação prevista no art. 55 da Lei n. ${ }^{\circ}$ 7.244/84 - Lei do Juizado de Pequenas Causas² (OLIVEIRA, 2011).

Todavia, foi só com o Código de Defesa do Consumidor, quando se introduziu o $\S 6^{\circ}$ ao art. $5^{\circ}$ da Lei n. ${ }^{\circ}$ 7.347/85 - Lei de Ação Civil Pública, que o ajuste alcançou abrangência maior, eis que, como norma geral, possibilitou ao Ministério Público e outros órgãos legitimados a solução extrajudicial de conflitos de direitos transindividuais indisponíveis (RODRIGUES, 2011, p. 85-87), gênero do qual são espécies os direitos difusos, os direitos coletivos em sentido estrito e os direitos individuais homogêneos (OLIVEIRA, 2011).

\footnotetext{
${ }^{1}$ Art. 211.Os órgãos públicos legitimados poderão tomar dos interessados compromisso de ajustamento de sua conduta às exigências legais, o qual terá eficácia de título executivo extrajudicial. (BRASIL, 1990).

${ }^{2}$ Art. 55. Valerá como título executivo o acordo celebrado pelas partes, por instrumento escrito, referendado pelo órgão competente do Ministério Público. (BRASIL, 1984).
} 
Quando realizado no âmbito administrativo tem como escopo propiciar a reparação do dano civil à coletividade, cessando o ato ilegal pelo agente causador do dano, sem que seja necessário o ajuizamento de uma demanda judicial. Nada impede, contudo, que este ajuste também seja realizado durante o processo judicial, pondo fim ao litígio.

\footnotetext{
Art. $5^{\circ}$ Têm legitimidade para propor a ação principal e a ação cautelar:

[...]

$\S 6^{\circ}$ Os órgãos públicos legitimados poderão tomar dos interessados compromisso de ajustamento de sua conduta às exigências legais, mediante cominações, que terá eficácia de título executivo extrajudicial. (BRASIL, 1985).
}

Diferentemente da transação típica, em que o ajuste ocorre entre os próprios titulares do direito individual disponível, atuando o membro do Ministério Público e os advogados das partes como mero coadjuvantes - pois apenas garantem que as partes tenham conhecimento das implicâncias jurídicas da transação -, no ajustamento de conduta os legitimados para a ação civil pública são partes do acordo, embora não sejam os titulares diretos do direito envolvido, porquanto, se tratam de direitos transindividuais indisponíveis (RODRIGUES, 2011, p. 95).

Perceba que o interesse tutelado é o da coletividade, e não propriamente o dos legitimados da ação civil pública (PINHO, 2018).

Quanto à natureza jurídica do termo de ajustamento de conduta, Geisa de Assis Rodrigues o classifica como uma espécie de conciliação, realizado extra ou judicialmente, pois permite a solução do conflito já instaurado ou a iniciar, diferenciando-se das transações típicas por inexistir concessões recíprocas (RODRIGUES, 2011, p. 130).

$\mathrm{O}$ agente ao aderir ao compromisso se propõe a cumprir certa conduta para atender às determinações legais, seja por meio de uma obrigação de fazer, não fazer, ou reparar o dano - ato unilateral de vontade, enquanto o órgão público tomador do compromisso não cede a qualquer direito transindividual, porque indisponível, mas busca, por meio deste método de solução de conflito, obter, no mínimo, a mesma solução que se obteria com o provimento judicial, visando sempre atingir ao fim do instituto (RODRIGUES, 2011).

O termo de ajustamento de conduta tem como finalidade tutelar os direitos transindividuais, de forma preventiva ou reparadora, e não favorecer o agente violador do direito (RODRIGUES, 2011, p.100). Por isso, a margem do acordo, nestes casos, limita-se ao modo, ao tempo ou ao lugar de cumprimento da obrigação para a reparação do dano coletivo causado pelo agente (PINHO, 2018). 
Assim, poder-se-ia dizer que o termo de ajustamento de conduta seria uma espécie de acordo, com características próprias, de caráter facultativo, logo não obrigatório, mas que se diferencia das transações típicas, hipótese na qual as partes se dispõe de parte de seus interesses para alcançar a solução consensual do conflito.

A despeito deste entendimento, há uma tendência de afastar ou minimizar a rigidez que envolve a indisponibilidade dos bens públicos, para ampliar a margem de negociabilidade dos termos de ajustamento de conduta e alcançar um sistema coletivo adequado (PINHO, 2018).

Sem que se renuncie a qualquer direito, os legitimados aos acordos devem ponderar, a partir do caso concreto, qual a melhor solução e de que forma o interesse público estaria de fato sendo preservado.

É certo que a análise sobre a viabilidade da negociação em matéria coletiva, desde que não se renuncie ao direito material coletivo em sua substância, requer aguçada sensibilidade do órgão público legitimado. Deve haver a verificação então, em concreto, do princípio da proporcionalidade em todos os seus níveis ou subníveis de aferição - necessidade, adequação e proporcionalidade em sentido estrito - de modo a se escolher a via mais apta para a melhor efetivação possível do direito violado, com a reparação imediata da conduta ilícita. (PINHO, 2018).

Neste sentido é que ao se admitir a realização do termo de ajustamento de conduta nas hipóteses de improbidade administrativa, não se está a beneficiar o agente público ímprobo, mas a buscar a solução mais célere e efetiva para a proteção da moralidade administrativa e tutela do patrimônio público, por meio do ressarcimento ao erário, promovendo a própria eficiência da Administração Pública.

Sabe-se que a realização de acordos é infinitamente mais célere, menos burocrática e menos onerosa do que a movimentação do Poder Judiciário.

Segundo o relatório emitido pelo Conselho Nacional de Justiça - CNJ, em 2018, o custo para o funcionamento do Poder Judiciário, excluídas as despesas com os servidores inativos para o pagamento de pensões e aposentadoria foi de $\mathrm{R} \$ 76,8$ bilhões de reais, equivalente a $\mathrm{R} \$ 368,40$ (trezentos e sessenta e oito reais e quarenta centavos) por habitante, correspondendo a $1,1 \%$ do Produto Interno Brasileiro - PIB. Desse total de despesas, 57\% (cinquenta e sete por cento) é direcionado à Justiça estadual, que movimenta $80 \%$ (oitenta por cento) dos processos judiciais (BRASIL, 2019). 
A conciliação, embora seja uma política adotada pelo CNJ desde 2006 e com crescente avanço, alçado a fundamento processual com o Código de Processo Civil de 2015 e resultado do princípio da cooperação, apenas $11,5 \%$ (onze e meio por cento) das sentenças proferidas no ano de 2018 referem-se às homologatórias de acordos, em contraponto às decisões terminativas (BRASIL, 2019).

No que se refere ao tempo médio para a condenação definitiva em ações de improbidade administrativa na Justiça Estadual e Federal, o Instituto Não Aceito Corrupção, associação civil, sem fins econômicos, fundada em 2015, apresentou, a partir de dados coletados do Conselho Nacional de Justiça - CNJ, o tempo de 6 (seis) anos e 1 (um) mês, considerando os processos julgados entre 1995 e julho de 2016 (INSTITUTO NÃO ACEITO CORRUPÇÃO, 2017).

A exigência da homologação pelo magistrado permitirá um controle dos seus termos, garantindo a resolução efetiva da controvérsia e da tutela dos direitos transindividuais. $\mathrm{O}$ Conselho Superior do Ministério Público do Estado de Minas Gerais ao editar a Resolução n. ${ }^{\circ}$ 03 de 23 de novembro de 2017, inclusive, reconheceu a homologação judicial como requisito necessário à celebração judicial do compromisso de ajustamento de conduta nas hipóteses de improbidade administrativa (MINAS GERAIS, 2017).

Dessa forma, a realização dos compromissos de ajustamento de conduta nas ações de improbidade administrativas tem como propósito garantir uma tutela jurisdicional mais efetiva e a concretização da duração razoável do processo, quando realizados judicialmente e desde que cumprida a finalidade da Lei n. ${ }^{\circ}$ 8.492/92 e homologada em juízo.

\section{OS ACORDOS NAS AÇÕES DE IMPROBIDADE ADMINISTRATIVA}

O combate à corrupção ou ao ato de se corromper ou de se comportar contra a ética ou a moral, com intuito de obter vantagens indevidas, e a preocupação com o trato da coisa pública não é nenhuma novidade da Constituição de 1988 - CR/88.

Já na primeira Constituição Republicana de 1981, atribuía-se como crime de responsabilidade do Presidente da República os atos que atentassem contra a probidade administrativa (MACHADO, 2017, p. 56).

Todavia, foi com a Constituição de 1988, no período pós redemocratização, que a responsabilização pela prática de atos de improbidade se estendeu, expressamente, a todos os 
agentes públicos, consoante estabelecido no art. $37, \S 4^{\circ}$ da $\mathrm{CR} / 88$, num verdadeiro controle do Poder Administrativo, tornando-se direito fundamental do cidadão a boa administração e a condução responsável dos assuntos do Estado pelo governo (MOTTA, 2012, p. 152).

\footnotetext{
Art. 37. A administração pública direta e indireta de qualquer dos Poderes da União, dos Estados, do Distrito Federal e dos Municípios obedecerá aos princípios de legalidade, impessoalidade, moralidade, publicidade e eficiência e, também, ao seguinte:

[...]

$\S 4^{\circ}$ Os atos de improbidade administrativa importarão a suspensão dos direitos políticos, a perda da função pública, a indisponibilidade dos bens e o ressarcimento ao erário, na forma e gradação previstas em lei, sem prejuízo da ação penal cabível. (BRASIL, 1988).
}

E para dar efetividade à norma constitucional, entrou em vigor a Lei n. ${ }^{\circ}$ 8.429/92 Lei de Improbidade Administrativa que definiu, dentre outras disposições, quais seriam os atos ímprobos, suas sanções e o procedimento administrativo e judicial cabível na apuração e responsabilização civil dos sujeitos ativos da improbidade (BRASIL, 1992).

Dentre as suas disposições, o art. $17, \S 1^{\circ}$ mereceu grande destaque e repercussão jurídica porque vedava a transação, o acordo ou a conciliação nas ações de que se tratava a Lei, cujo fundamento pautava-se, basicamente, na indisponibilidade do interesse público (DI PIETRO, 2019, p. 1832), caracterizada pela busca na preservação do patrimônio público e da moralidade administrativa.

\subsection{A MEDIDA PROVISÓRIA N. ${ }^{\circ} 703 / 15$}

A impossibilidade de realizar acordos, transações ou conciliações no âmbito das ações de improbidade administrativa tinha previsão no art. $17, \S 1^{\circ}$ da Lei de Improbidade Administrativa (BRASIL, 1992), a despeito dos acordos e transações existentes no ordenamento jurídico realizados com os agentes públicos ou terceiros que praticaram fatos possíveis de serem imputados como de improbidade administrativa.

A Lei n. ${ }^{\circ}$ 12.846/13 - Lei Anticorrupção, por exemplo, no âmbito administrativo, prevê a possibilidade de realização do acordo de leniência entre o ente público e a pessoa jurídica responsável pela prática de atos lesivos à administração pública e que atentem contra o patrimônio público nacional ou estrangeiro, contra os compromissos internacionais assumidos pelo Brasil ou contra os princípios da administração pública (BRASIL, 2013). 
Todavia, consoante seus artigos 18 e 30, a celebração do acordo de leniência na esfera administrativa não obstava que as pessoas jurídicas, ou eventuais sócios ou responsáveis legais, fossem responsabilizados pelos mesmos atos na esfera judicial (BRASIL, 2013). Tal fato, obviamente, desestimulava-os a colaborarem com as investigações do poder público, impedindo que o acordo de leniência fosse utilizado tal como se esperava para o combate à corrupção (MACHADO, 2017, p. 187).

Assim é que a isenção na aplicação da sanção de proibição de contratar com o poder público ou receber incentivos, prevista na Lei Anticorrupção, tornou-se irrelevante, diante a possibilidade de responsabilização civil nos termos da Lei de Improbidade Administrativa.

Com vista a aperfeiçoar a aplicação do acordo de leniência, e em grande parte tornando-o mais eficiente, foi editada a Medida Provisória $n^{\circ} 703$ de 18 de dezembro de 2015,que alterou a Lei Anticorrupção, para prever que o acordo de leniência impediria o ajuizamento ou prosseguimento das ações judicias previstas no art. 19 da sua lei e das ações de improbidade administrativa, ou de natureza civil (BRASIL, 2015).

\footnotetext{
Art. 16. A autoridade máxima de cada órgão ou entidade pública poderá celebrar acordo de leniência com as pessoas jurídicas responsáveis pela prática dos atos previstos nesta Lei que colaborem efetivamente com as investigações e o processo administrativo, sendo que dessa colaboração resulte:

[...]

$\S$ 11. O acordo de leniência celebrado com a participação das respectivas Advocacias Públicas impede que os entes celebrantes ajuizem ou prossigam com as ações de que tratam o art. 19 desta Lei e o art. 17 da Lei $n^{\circ} 8.429$, de 2 de junho de 1992, ou de ações de natureza civil. (Incluído pela Medida provisória $\mathrm{n}^{\circ} 703$, de 2015)

$\S 12$. O acordo de leniência celebrado com a participação da Advocacia Pública e em conjunto com o Ministério Público impede o ajuizamento ou o prosseguimento da ação já ajuizada por qualquer dos legitimados às ações mencionadas no $\S$ 11. (Incluído pela Medida provisória $\mathrm{n}^{\circ} 703$, de 2015) [...]

Art. 18. Na esfera administrativa, a responsabilidade da pessoa jurídica não afasta a possibilidade de sua responsabilização na esfera judicial, exceto quando expressamente previsto na celebração de acordo de leniência, observado o disposto no $\S 11$, no $\S 12$ e no $\S 13$ do art. 16. (Redação dada pela Medida provisória $\mathrm{n}^{\circ} 703$, de 2015) (BRASIL, 2013).
}

Consequentemente, a referida Medida Provisória revogou expressamente o $\S 1^{\circ}$ do art. 17 da Lei de Improbidade Administrativa (BRASIL, 1992).

Ocorre que, segundo o Ato Declaratório do Presidente da Mesa do Congresso Nacional n. ${ }^{\circ} 27$ de 2016, a Medida Provisória n. ${ }^{\circ}$ 703/15 teve sua vigência encerrada em 29 de maio de 2016, porque não convertida em lei, nos termos do art. $62, \S \S 3^{\circ}$ e $7^{\circ}$ da $C R / 88$, 
restabelecendo a proibição de transações, acordos ou conciliação nas ações de que tratava a Lei de Improbidade Administrativa (BRASIL, 2016).

\subsection{RESOLUÇÕES DO CNMP E CSMP DO ESTADO DE MINAS GERAIS}

$\mathrm{Na}$ tentativa de promover a justiça e de reduzir os litígios, bem como garantir a efetividade dos compromissos de ajustamento de conduta, realizados no âmbito dos inquéritos civis e ações civis públicas, o Conselho Nacional do Ministério Público - CNMP editou a Resolução n. ${ }^{\circ} 179$ de 26 de julho de 2017, que dentre outras coisas, estipulou, em seu art. $1^{\circ}$, $\S 2^{\circ}$, ser “cabível compromisso de ajustamento de conduta nas hipóteses configuradoras de improbidade administrativa, sem prejuízo do ressarcimento ao erário e da aplicação de uma ou algumas das sanções previstas em lei, de acordo com a conduta ou o ato praticado." (BRASIL, 2017).

Veja que a ação de improbidade administrativa é considerada majoritariamente uma espécie de ação civil pública, porque, em última análise, tutela os interesses difusos e coletivos, como a moralidade e a probidade administrativa, compondo o chamado microssistema processual de tutela coletiva, embora disponha de procedimento próprio e específico (PAZZAGLINI FILHO, 2018, p 172).

Tal conclusão tem respaldo no art. 129, inciso III da CR/88 (BRASIL, 1988) que alargou as hipóteses de proteção da Lei de Ação Civil Pública (BRASIL, 1985), para alcançar o patrimônio público e social, do meio ambiente e de outros interesses difusos e coletivos, estes entendidos como qualquer interesse público ou geral (DI PIETRO, 2019, p 1.761 e 1.830).

Ainda, essa Resolução admite a realização do acordo em qualquer fase da investigação, inquérito civil ou processo judicial, desde que assinado pelo representante do Ministério Público e que não implique em renúncia a direito ou interesse difuso ou coletivo e individuais homogêneos, devendo se ater ao caso concreto, consoante o disposto em seu art. $1^{\circ}, \S 1^{\circ}$ e seu art. $3^{\circ}$ (BRASIL, 2017).

Por sua vez, a Resolução do Conselho Superior do Ministério Público do Estado de Minas Gerais - CSMP n. 03 de 23 de novembro de 2017, seguindo a mesma diretriz, regulamentou, no âmbito estadual, o compromisso de ajustamento de conduta envolvendo as hipóteses configuradoras de improbidade administrativa, previstas na Lei de Improbidade 
Administrativa, sem prejuízo do ressarcimento ao erário e da aplicação de uma ou de algumas das sanções previstas na Lei, conforme o caso concreto (BRASIL, 2017).

Em suas considerações ressaltou a necessidade de efetivar os direitos e garantias fundamentais de acesso a uma justiça mais célere e eficiente, através da autocomposição dos conflitos, em contrapartida à crescente judicialização e tradicional resolução dos conflitos pelo Poder Judiciário (BRASIL, 2017).

Apontou os princípios e normas trazidas pelo Código de Processo Civil de 2015 que incorporaram e enalteceram os mecanismos de autocomposição, bem como a colaboração premiada, no campo penal, e o acordo de leniência, no campo administrativo, como instrumentos capazes de afastar as sanções típicas previstas nas Leis em contrapartida à realização do bem jurídico protegido (BRASIL, 2017).

Segundo o seu art. $3^{\circ}$, a realização do termo de ajustamento de conduta, de iniciativa do Ministério Público ou do responsável pelos atos de improbidade, pessoa física ou jurídica, tem como objetivo a aplicação mais rápida e eficaz das sanções previstas na Lei de Improbidade Administrativa, contribuindo para prevenir e reprimir as condutas ímprobas e desde que, obrigatoriamente, haja o compromisso de reparar integralmente o dano sofrido; de transferir ou devolver, sem ônus para a entidade lesada, os bens, os direitos ou os valores adquiridos com a infração; de cessar a conduta ilícita; de oferecer garantias para o pagamento da multa civil, ressarcimento e transferência (BRASIL, 2017).

E a depender da extensão do dano e do grau de censura da conduta ímproba, nos termos do art. $4^{\circ}$ da Resolução n. ${ }^{\circ} 03$ do CSMP de Minas Gerais, o termo de ajustamento de conduta também poderá exigir do agente público o compromisso de pagamento de multa civil; de não contratar com o Poder Público ou receber benefícios ou incentivos fiscais ou creditícios, direta ou indiretamente, ainda que por intermédio de pessoa jurídica da qual seja sócio majoritário, por período determinado; de renunciar à função pública; de reparar os danos morais coletivos; e de renunciar ao direito de candidatar-se a cargos públicos eletivos, por períodos determinados, sempre limitado ao máximo estipulado no art. 12 da Lei de Improbidade Administrativa (MINAS GERAIS, 2017).

Além disso, consoante o art. $5^{\circ}$ da Resolução n. 03 do CSMP de Minas Gerais, “o Compromisso de Ajustamento de Conduta poderá ser tomado em qualquer fase da investigação, nos autos de inquérito civil ou procedimento preparatório, ou no curso da ação judicial." (MINAS GERAIS, 2017). 
Na última hipótese, os acordos dependem de homologação judicial, condição também exigida para o caso de aplicação do compromisso de renúncia à capacidade eleitoral passiva. Se realizada durante o inquérito civil ou procedimento preparatório para ação judicial, basta a homologação do Conselho Superior do Ministério Público.

\subsection{O PACOTE ANTICRIME E A LEI DE IMPROBIDADE ADMINISTRATIVA}

Em 24 de dezembro de 2019, em edição extra, foi publicada a Lei n. ${ }^{0}$ 13.964/19 Pacote Anticrime que, além de aperfeiçoar a legislação penal e processual penal, também trouxe significativas mudanças na esfera administrativa, em especial, na Lei n. ${ }^{\circ}$ 8.429/92 ao alterar o seu art. $17, \S 1^{\circ}$ para admitir a celebração de acordo de não persecução cível, cuja vigência teve início em 23 de janeiro de 2020 (BRASIL, 2019).

A alteração fez parte do chamado pacote anticrime proposto pelo Ministro da Justiça e Segurança Pública Sérgio Moro e por uma comissão de juristas coordenada pelo ministro do Supremo Tribunal Federal Alexandre de Moraes, parcialmente alterado pelos parlamentares, depois de submetida a diversos debates e que culminou na sanção e publicação da Lei n. ${ }^{\circ}$ 13.964/19 (BRASIL, 2019).

Dentre as inúmeras modificações na espera penal e processual penal, pode-se citar a ampliação das hipóteses configuradoras de legítima defesa; o aumento da pena máxima privativa de liberdade; a não persecução penal para crimes sem violência e com pena mínima de quatro anos, salvo crimes de improbidade administrativa; a criação dos juízes garantia; a proibição de progressão de regime aos presos condenados por integrar organização criminosa e a vedação às saídas temporárias de presos condenados por crimes hediondos com resultado morte (BRASIL, 2019).

No âmbito cível, a aprovação do Pacote Anticrime também surtiu efeitos de grande relevância jurídica no combate à corrupção. Trata-se da possibilidade de realização de acordos de não persecução civil nas hipóteses de improbidade administrativa.

O art. $6^{\circ}$ da Lei n. ${ }^{\circ} 13.964 / 19$ alterou a redação do art. $17, \S 1^{\circ}$ da Lei de Improbidade Administrativa e acrescentou o $§ 10-\mathrm{A}$, que passou a prever:

Art. 17. A ação principal, que terá o rito ordinário, será proposta pelo Ministério Público ou pela pessoa jurídica interessada, dentro de trinta dias da efetivação da medida cautelar. 
$\S 1^{\circ}$ As ações de que trata este artigo admitem a celebração de acordo de não persecução cível, nos termos desta Lei.

$[\ldots]$

§ 10-A. Havendo a possibilidade de solução consensual, poderão as partes requerer ao juiz a interrupção do prazo para a contestação, por prazo não superior a 90 (noventa) dias. (BRASIL, 2019).

Observa-se que não se trata de permitir a celebração de acordos em toda e qualquer fase das ações de improbidade, de que trata a Lei n. ${ }^{\circ}$ 8.429/92. A partir de uma leitura mais atenta do dispositivo, bem como das vedações ocorridas a outros parágrafos propostos no pacote anticrime, extrai-se que a permissão se restringiu ao momento do inquérito civil ou durante o juízo prévio de admissibilidade da petição inicial nas ações de improbidade administrativa.

Segundo o vetado art. 17-A, $\S 2^{\circ}$ da Lei, os acordos também poderiam ser celebrados no curso da ação de improbidade. A justificativa ao veto foi de que esta hipótese comprometeria a eficiência dos acordos realizados em momento anterior à demanda principal, pois permitiria ao infrator continuar litigando judicialmente e depois, caso desejasse, optar pela transação judicial, deixando de atender aos propósitos do instrumento de resolução consensual de conflito - reparação mais célere e desaforamento do Poder Judiciário (BRASIL, 2019).

Assim, percebe-se que a alteração normativa permitiu apenas a celebração de acordos para a não persecução civil, ou seja, em momento anterior ao processo principal, mantendo-se a vedação ou impossibilidade de fazê-lo no curso da demanda judicial.

Esclareça-se que o procedimento previsto na Lei de Improbidade Administrativa tem caráter especial, com atos próprios e diferentes do rito ordinário tratado no Código de Processo Civil, muito embora o art. 17 da Lei n. ${ }^{\circ}$ 8.429/92 a nomeie como de rito ordinário (CARVALHO FILHO, 2019, p.1.090).

A ação de improbidade administrativa, por exemplo, apresenta dois procedimentos distintos e não autônomos: o procedimento de juízo prévio de admissibilidade da demanda e o procedimento principal. No primeiro momento, distribuída a petição inicial, o juízo notificará o requerido para apresentar sua defesa prévia, e ao final, munido das primeiras informações colhidas, receberá ou rejeitará a peça de ingresso, seja pela ausência do ato de improbidade, pela improcedência do pedido ou pela inadequação da via eleita (CARVALHO FILHO, 2019, p. 1.090; PAZZIGLINI FILHO, 2018, p. 174). 
A notificação do requerido para apresentação da defesa prévia constitui um contraditório preambular realizado em fase anterior à citação do réu e, portanto, da formação regular da relação processual (CARVALHO FILHO, 2019, p. 1.090; PAZZIGLINI FILHO, 2018, p. 178).

Por isso, os acordos admitidos são aqueles celebrados durante o inquérito civil ou no juízo prévio de admissibilidade da ação de improbidade, mas não durante a ação principal.

Outros vetos importantes a respeito do assunto também ocorreram, como aquele à proposta de inclusão do art. $17-\mathrm{A}, \S \S 1^{\circ}, 3^{\circ}, 4^{\circ}$ e $5^{\circ}$ da Lei n. ${ }^{\circ} 8.249 / 92$, que previa uma breve regulamentação sobre os acordos de não persecução civil, estabelecendo a pactuação mínima exigida entre o Ministério Público e o investigado ou demandado.

\footnotetext{
Art. 17-A. O Ministério Público poderá, conforme as circunstâncias do caso concreto, celebrar acordo de não persecução cível, desde que, ao menos, advenham os seguintes resultados:

I - o integral ressarcimento do dano;

II - a reversão, à pessoa jurídica lesada, da vantagem indevida obtida, ainda que oriunda de agentes privados;

III - o pagamento de multa de até $20 \%$ (vinte por cento) do valor do dano ou da vantagem auferida, atendendo a situação econômica do agente."

"§ $1^{\circ} \mathrm{Em}$ qualquer caso, a celebração do acordo levará em conta a personalidade do agente, a natureza, as circunstâncias, a gravidade e a repercussão social do ato de improbidade, bem como as vantagens, para o interesse público, na rápida solução do caso."

"§ $3^{\circ}$ As negociações para a celebração do acordo ocorrerão entre o Ministério Público e o investigado ou demandado e o seu defensor.

$\S 4^{\circ} \mathrm{O}$ acordo celebrado pelo órgão do Ministério Público com atribuição, no plano judicial ou extrajudicial, deve ser objeto de aprovação, no prazo de até 60 (sessenta) dias, pelo órgão competente para apreciar as promoções de arquivamento do inquérito civil.

$\S 5^{\circ}$ Cumprido o disposto no $\S 4^{\circ}$ deste artigo, o acordo será encaminhado ao juízo competente para fins de homologação. (BRASIL, 2019)
}

As razões ao veto, neste caso, ocorreram porque apenas os agentes ministeriais foram reconhecidos como legitimados para as transações, em contradição à previsão legal que confere também aos entes públicos afetados a legitimidade para ajuizar as ações de improbidade administrativa (BRASIL, 2019). Se podem ajuizar uma demanda judicial, por óbvio deveriam também poder celebrar os acordos. “Art. 17. A ação principal, que terá o rito ordinário, será proposta pelo Ministério Público ou pela pessoa jurídica interessada, dentro de trinta dias da efetivação da medida cautelar.” (BRASIL, 1992). 
Fato é que todos os parágrafos foram vetados, inexistindo por ora qualquer regulamentação sobre os acordos. Assenta-se que o alterado art. 17, $\S 1^{\circ}$ da Lei n. ${ }^{\circ} 8.249 / 92$, estabelece a possibilidade de realização dos acordos, segundo ou nos termos da Lei.

Logo, questiona-se: diante a omissão regulatória legislativa é possível realizar os acordos de não persecução civil? Em sendo a resposta positiva, qual o parâmetro ou os limites a utilizar? Poderiam as Resoluções do CNMP e CSMP de Minas Gerais suprir a ausência de regulamentação legal?

\section{A COMPLETUDE DO ORDENAMENTO JURÍDICO: REFLEXO NOS ACORDOS DE NÃO PERSECUÇÃO CIVIL DE IMPROBIDADE ADMINISTRATIVA}

Sabe-se que um Estado, politicamente organizado e sustentado sob uma base majoritariamente legalista - sistema civil law - possui na Lei o instrumento principal de regulação do ente público e das relações resultantes do convívio social.

O Estado moderno, contudo, ao tentar se organizar e regular a vida em sociedade, a partir da criação de leis, não conseguiu e nem poderia abarcar todas as relações sociais que tem ou poderia ter relevância jurídica, eis que o processo legislativo não caminha nos mesmos passos que a evolução e dinamismo da sociedade moderna (SOUZA FILHO, 1997).

A sociedade pós-moderna, cada dia maior e mais complexa, com inúmeras relações públicas ou privadas, acabam por propiciar a criação de mais normas jurídicas, tornando o ordenamento jurídico ainda mais complexo e numeroso. Além da Constituição da República, que deve ser tomada como fundamento de validade de todas as normas jurídicas, em razão do princípio da supremacia da constituição (MARINONI; MITIDIEIRO; SARLET, 2017, p 240), inúmeras leis esparsas ou microssistemas são criados, tornando ainda mais difícil manter a integridade, coerência e completude do sistema.

Ao descrever sobre o ordenamento jurídico como um conjunto ou complexo de normas existentes em uma sociedade, Norberto Bobbio já apontava os três grandes problemas que circunscreviam a definição do instituto. Primeiro, se era possível conceber o ordenamento como uma unidade, considerando as inúmeras normas que o compunham; segundo, se seria considerado um sistema, diante suas aparentes antinomias; e terceiro, se poderia ser completo, desprovido de qualquer lacuna (BOBBIO, 1995, p 34). 
A despeito das considerações sobre a unidade do ordenamento jurídico, resultante da norma fundamental, hierarquicamente superior e que confere validade a todas as outras normas inferiores, e da coerência necessária a repelir antinomias, este capítulo se propõe discutir a completude do ordenamento jurídico e as soluções dadas, a partir da teoria do ordenamento jurídico de Norberto Bobbio para a hipótese das lacunas reais do sistema.

Segundo Norberto Bobbio, a completude do ordenamento jurídico existe na medida em que se torna possível, mesmo diante a ausência normativa sobre determinado interesse jurídico, que o juiz julgue as controvérsias que lhe foram apresentadas a partir das normas que compõe o próprio sistema (BOBBIO, 1995).

Em suma, rebate o dogma da completude do ordenamento jurídico defendido pela escola da exegese, para quebrar as amarras do monopólio estatal e diante as lacunas buscar outras fontes jurídicas, que não a lei, para a perfeição do sistema. Se para a escola da exegese o intérprete deveria apenas tornar explicito o que já estava implícito na lei, para a escola do direito livre, é preciso se libertar e buscar uma solução para além das regras pré-constituídas (BOBBIO, 1995).

Diante o grande receio de que a liberdade conferida aos juízes na aplicação do Direito pudesse levar a uma desordem ou anarquia, foi travada uma batalha entre as escolas da exegese e do direito livre, cada qual defendendo a ausência ou não de lacunas no direito.

Sem adentrar a discussão pormenorizada do assunto, Norberto Bobbio conclui que as lacunas ou incompletude do ordenamento jurídico não estão na falta de uma norma a ser aplicada, pois assim, poder-se-ia utilizar da norma geral exclusiva - norma que regula todos os casos não regulamentados de maneira oposta àqueles regulamentados -, mas na falta de critérios válidos para dizer qual norma deve ser aplicada, a norma geral exclusiva ou a norma geral inclusiva - norma que regula os casos não regulamentados de forma idêntica aqueles semelhantes e regulamentados (BOBBIO, 1995).

Apresentou ainda a diferença entre as lacunas ideológicas e as reais. Enquanto a primeira refere-se à ausência de norma justa - norma que desejava existir em um ordenamento tido como ideal -, a segunda consiste na falha atual do ordenamento jurídico já posto. É como se a primeira fosse as chamadas lacunas impróprias e a última as lacunas próprias. Conclui que o problema da completude do ordenamento reside em como podem ser eliminadas as lacunas próprias (BOBBIO, 1995). 
As lacunas próprias ainda podem ser subjetivas voluntárias ou involuntárias, a depender da vontade ou intenção do legislador, ou ainda objetivas, porque resultam do dinamismo e avanço das relações sociais extrapolando aos textos legislativos preexistentes.

Independente do motivo, o reconhecimento das lacunas tem grande relevância jurídica porque envolve o direito à existência de uma norma reguladora do exercício de determinado direito consagrado, a ser solucionado pelo juízo (SOUZA FILHO, 1997), a partir das ferramentas e instrumentos conferidos pelo próprio ordenamento jurídico, conforme já advertido.

No caso brasileiro, o art. $4^{\circ}$ do Decreto-Lei n. ${ }^{\circ}$ 4.657/42 - Lei de Introdução às Normas do Direito Brasileiro (LINDB) estabelece que "quando a lei for omissa, o juiz decidirá o caso de acordo com a analogia, os costumes e os princípios gerais de direito" (BRASIL, 1942).

Trata-se os costumes de mecanismo para a chamada heterointegração - supressão das lacunas a partir de ordenamentos diversos ou fontes diferentes daquela predominante no sistema jurídica, no caso, a lei, e a analogia e os princípios gerais de direito de métodos de autointegração - forma de supressão das lacunas a partir de regras encontradas no âmbito normativo já existente (BOBBIO, 1995).

\footnotetext{
Entende-se por "analogia" o procedimento pelo qual se atribui a um caso nãoregulamentado a mesma disciplina que a um caso regulamentado semelhante. [...] A analogia é certamente o mais típico e o mais importante dos procedimentos interpretativos de um determinado sistema normativo: é o procedimento mediante o qual se explica a assim chamada tendência de cada ordenamento jurídico a expandirse além dos casos expressamente regulamentados. (BOBBIO, 1995)
}

Ainda, explica que ara aplicar a analogia não basta o silogismo ou semelhança entre os fatos regulamentados e não regulamentados. É preciso uma semelhança relevante capaz de atribuir uma norma a outro caso, ou seja, a razão de existir da lei deve cobrir ambas as situações. A analogia se divide ainda em analogia legis ou propriamente dita - utiliza-se a regra existente para caso semelhante -, analogia iuris - busca a integração a partir de um análise sistêmica do todo ou de parte do ordenamento, também conhecida como os princípios gerais de direito - e interpretação extensiva - alarga-se o alcance de uma norma jurídica (BOBBIO, 1995).

Dessa forma, embora o ordenamento jurídico não seja capaz de contemplar toda e qualquer relação ou interesse jurídico relevante, em função da própria dinamicidade e 
mutações que as relações econômicas, familiares, políticas e sociais sofrem, há instrumentos jurídicos e hermenêuticos capazes de unificar, sistematizar e integrar as normas jurídicas existentes, de forma a resolver os conflitos existentes e garantir a segurança jurídica necessária à estabilização da ordem social.

\subsection{APLICAÇÃO ANALÓGICA AOS ACORDOS DE NÃO PERSECUÇÃO CIVIL NÃO REGULAMENTADOS}

Feita esta breve explanação sobre o sistema de integração das lacunas legislativas, e considerando, como já exposto em capítulo anterior ${ }^{3}$, que os acordos de não persecução civil admitidos nas hipóteses de improbidade administrativa ainda carecem de regulamentação, seria possível aplicar analogicamente as Resoluções do CNMP ou CSMP de Minas Gerais, de forma a garantir eficácia à norma infraconstitucional?

O acordo de não persecução civil foi introduzido pelo Pacote Anticrime e constitui um meio de solução alternativa e consensual de conflito, que pode ser realizado durante a fase do inquérito civil ou no juízo provisório de admissibilidade da petição inicial da ação de improbidade administrativa. Contudo, embora previsto o direito, não há na Lei de Improbidade Administrativa a descrição dos limites que circundam esta avença. Dessa forma, não se sabe qual o conteúdo, a forma e os requisitos necessários à celebração do acordo.

De fato, o que há atualmente descrito no ordenamento jurídico são as regras próprias do acordo de leniência e da delação premiada, instrumentos de combate à corrupção pública e de tutela dos interesses públicos, bem como as Resoluções do CNMP e CSMP de Minas Gerais.

Os dois primeiros instrumentos têm o objetivo de obter do agente a colaboração efetiva com as investigações civis e/ou criminais, auxiliando os órgãos públicos no processo administrativo ou criminal, a partir da identificação dos demais envolvidos na atividade ou ato ilícito, bem como na obtenção célere das provas da infração, até a recuperação do proveito ou produto obtido com o crime (MACHADO, 2017; MENDONÇA, 2017).

Já os acordos de não persecução civil têm como escopo solucionar a controvérsia de forma mais célere e efetiva para a proteção da moralidade administrativa e a tutela do patrimônio público. Não há aqui qualquer objetivo direcionado à obtenção de informações

${ }^{3}$ Ver Capítulo 3, item 3.3. 
para desvelar espécie de ilícito, o que, afasta a possibilidade de se utilizar da analogia, segundo a teoria geral do direito de Norberto Bobbio (1995), tal como anteriormente citado. ${ }^{4}$

As Resoluções do CNMP e CSMP de Minas Gerais, por sua vez, tratam especificamente sobre os compromissos de ajustamento de conduta nas hipóteses de improbidade administrativa (BRASIL, 2017; MINAS GERAIS, 2017), o que, a priori, poderia se admitir como diretriz para a realização dos acordos de não persecução civil. Todavia, sua utilização merece cautela.

Segundo a Resolução n. ${ }^{\circ} 03$ do CSMP de Minas Gerais apenas os acordos realizados no curso da ação judicial devem ser homologados pelo juízo, bastando a homologação do Conselho Superior do Ministério Público quando celebrados durante o inquérito civil ou procedimento preparatório para ação judicial (MINAS GERAIS, 2017).

Além de violar o direito amplo de acesso à justiça dos investigados, bem como impedir o controle das avenças que tem como objeto a negociação de interesses públicos, essa assertiva contraria a vontade inicial do legislador que, na proposta de inclusão do art. 17-A, $\$ 5^{\circ}$ da Lei n. ${ }^{\circ} 8.249 / 92$ (BRASIL, 1992), exigia a homologação judicial em todos os acordos celebrados.

\section{CONCLUSÃO}

As ações de improbidade administrativa, consagradas na Lei n. ${ }^{\circ}$ 8.429/92 - Lei de Improbidade Administrativa, tiveram e ainda têm grande importância jurídica e política no combate à corrupção e à preservação da moralidade administrativa, permitindo a responsabilização civil dos agentes que praticam atos de improbidade (BRASIL, 1992).

Coerente com a nova ordem jurídica processual e tantos outros instrumentos de solução consensual de conflitos admitidos, bem como a necessidade de uma solução mais célere e eficaz das controvérsias envolvendo o combate à corrupção, a Lei n. ${ }^{\circ}$ 13.964/19 Pacote Anticrime (BRASIL, 2019), além de aperfeiçoar a legislação penal e processual penal, também trouxe significativas mudanças na esfera administrativa, em especial, na Lei $n .^{\circ}$ 8.429/92 (BRASIL, 1992).

$\mathrm{O}$ art. $17, \S 1^{\circ}$ da Lei de Improbidade Administrativa, que antes vedava a celebração de acordos, conciliação e transações nas hipóteses da Lei, passou a admitir a celebração de

\footnotetext{
${ }^{4}$ Ver Capítulo 4.
} 
acordo de não persecução cível, cuja vigência teve início em 23 de janeiro de 2020 (BRASIL, 1992).

Todavia, embora permitida a celebração dos acordos durante o inquérito civil ou no juízo prévio de admissibilidade da petição inicial das ações de improbidade administrativa, faltou a Lei regulamentar os termos, o objeto e os requisitos de validade dos acordos, prevista no Pacote Anticrime, mas vetado pelo Presidente da República.

A falta de norma regulamentadora, contudo, não pode ser óbice para a realização dos acordos. Segundo a teoria do ordenamento jurídico de Norberto Bobbio (1995), a completude do sistema jurídico pode ser alcançada por meio dos métodos de integração existentes, como a analogia, os costumes e os princípios gerais de direito, previstos no art. $4^{\circ}$ da LINDB (BRASIL, 1942).

No caso, concluiu-se que as Resoluções do CNMP e CSMP de Minas Gerais (BRASIL, 2017; MINAS GERAIS, 2017), que tratam especificamente sobre a celebração de compromisso de ajustamento de conduta nas hipóteses de improbidade administrativa, podem ser utilizadas como diretriz para a celebração dos acordos, merecendo especial cautela no que tange à necessidade de homologação judicial daqueles realizados durante o inquérito civil ou durante o juízo de admissibilidade da petição inicial nas ações de improbidade administrativa.

\section{REFERÊNCIAS}

BRASIL. Conselho Nacional de Justiça. Justiça em Números 2019, Brasília: CNJ, 2019.

BRASIL. Conselho Nacional do Ministério Público. Resolução no ${ }^{\circ} 179$, de 26 de julho de 2017. Regulamenta o $\$ 6^{\circ}$ do $\operatorname{art.~}^{\circ}$ da Lei $n^{\circ} 7.347 / 1985$, disciplinando, no âmbito do Ministério Público, a tomada do compromisso de ajustamento de conduta. Disponível em:http://www.cnmp.mp.br/portal/images/Resolucoes/Resolu\%C3\%A7\%C3\%A3o179.pdf.Acesso em: 25 jan. 2020.

BRASIL. Constituição da República Federativa do Brasil de 1988. Disponível em:http://www.planalto.gov.br/ccivil_03/constituicao/constituicao.htm. Acesso em: 25 jan. 2020.

BRASIL. Decreto-Lei n. ${ }^{\circ} 4.657$, de 4 de Setembro de 1942. Lei de Introdução às normas do Direito Brasileiro. Disponível em: http://www.planalto.gov.br/ccivil_03/decretolei/del4657compilado.htm. Acesso em: 25 jan. 2020. 
BRASIL. Lei 7.347/85, de 24 de julho de 1985. Disciplina a ação civil pública de responsabilidade por danos causados ao meio-ambiente, ao consumidor, a bens e direitos de valor artístico, estético, histórico, turístico e paisagístico (VETADO) e dá outras providências. Disponível em:

http://www.planalto.gov.br/ccivil_03/leis/L7347orig.htm. Acesso em: 25 jan. 2020.

BRASIL. Lei 8.429/92, de 02 de junho de 1992. Dispõe sobre as sanções aplicáveis aos agentes públicos nos casos de enriquecimento ilícito no exercício de mandato, cargo, emprego ou função na administração pública direta, indireta ou fundacional e dá outras providências. Disponível em: http://www.planalto.gov.br/ccivil_03/leis/L8429.htm. Acesso em: 25 jan. 2020.

BRASIL. Lei n. $^{\circ} 12.846$, de $1^{\circ}$ de agosto de 2013. Dispõe sobre a responsabilização administrativa e civil de pessoas jurídicas pela prática de atos contra a administração pública, nacional ou estrangeira, e dá outras providências. Disponível em: http://www.planalto.gov.br/ccivil_03/_ato2011-2014/2013/lei/112846.htm. Acesso em: 25 jan. 2020.

BRASIL. Lei n. ${ }^{\circ} 12.850 / 13$, de 02 de agosto de 2013. Define organização criminosa e dispõe sobre a investigação criminal, os meios de obtenção da prova, infrações penais correlatas e o procedimento criminal; altera o decreto-lei $n^{0} \mathbf{2 . 8 4 8}$, de 7 de dezembro de 1940 (Código Penal); revoga a lei $n^{0}$ 9.034, de 3 de maio de 1995; e dá outras providências. Disponível em: http://www.planalto.gov.br/ccivil_03/_ato20112014/2013/lei/112850.htm. Acesso em: 25 jan. 2020.

BRASIL. Lei 13.105/15, de 16 de março de 2015. Código de Processo Civil. Disponível em: http://www.planalto.gov.br/ccivil_03/_ato2015-2018/2015/lei/113105.htm. Acesso em: 19 ago. 2019.

BRASIL. Lei 13.964, de 24 de dezembro de 2019. Aperfeiçoa a legislação penal e processual penal. Disponível em: http://www.planalto.gov.br/ccivil_03/_ato20192022/2019/lei/L13964.htm\#art20. Acesso em: 25 jan. 2020.

BRASIL. Medida provisória n. ${ }^{\circ} 703$, de 18 de dezembro de 2015 . Altera a Lei $\mathbf{n}^{\mathbf{0}} \mathbf{1 2 . 8 4 6}$, de $1^{\circ}$ de agosto de 2013, para dispor sobre acordos de leniência. Disponível em:http://www.planalto.gov.br/ccivil_03/_Ato2015-2018/2015/Mpv/mpv703.htm. Acesso em: 10 jan. 2020.

BRASIL. Ministério da Justiça e Segurança Pública [notícias]. Lei Anticrime entra em vigor: Medidas modernizam legislação no combate à corrupção, organização criminosa e violência. Brasília, 2020. Disponível em: https://www.novo.justica.gov.br/news/lei-anticrimeentra-em-vigor. Acesso em: 25 jan. 2020. 
BRASIL. Presidência da República. Mensagem no 726, de 24 de dezembro de 2019. Brasília, Disponível em: http://www.planalto.gov.br/ccivil_03/_ato20192022/2019/Msg/VEP/VEP-726.htm. Acesso em: 25 jan. 2020.

BERTONCINI, Mateus. Crise da Jurisdição e a Resolução n. 179/2017 do Conselho Nacional do Ministério Público: é possível o ajustamento de conduta em matéria de improbidade administrativa?. Seqüência (Florianópolis), n. 79, p. 63-88, ago. 2018.Disponível em: http://www.planalto.gov.br/ccivil_03/_ato2019-2022/2019/Msg/VEP/VEP-726.htm. Acesso em: 25 jan. 2020.

BOBBIO, Norberto. Teoria do ordenamento jurídico. 6. ed. Brasília: Universidade de Brasília, 1995.

DI PIETRO, Maria Sylvia Zanella. Direito administrativo. 32. ed. Rio de Janeiro: Forense, 2019.

INSTITUITO NÃO ACEITO CORRUPÇÃO. Não aceito corrupção, 2017. Radiografia da improbidade (destaques). Disponível em:

http://naoaceitocorrupcao.org.br/2017/radiografia/radiografia/destaques/. Acesso em: 19 jan. 2020.

MACHADO, Pedro Antônio de Oliveira. Acordo de leniência e a lei de improbidade administrativa. Curitiba: Juruá, 2017.

MARINONI, Luiz Guilherme; MITIDIERO, Daniel; SARLET, Ingo Wolfgang. Curso de direito constitucional. 6. ed. São Paulo: Saraiva, 2017.

MENDONÇA, Andrey Borges de. In: BOTTINI, Pierpaolo Cruz; MOURA, Maria Thereza de Assis. Colaboração Premiada. São Paulo: Revista dos Tribunais, 2017. 53-104 p.

MINAS GERAIS (Estado). Conselho Superior do Ministério Público do Estado de Minas Gerais. Resolução CSMP n. ${ }^{\circ}$ 3, de 23 de novembro de 2017. Regulamenta, no âmbito do Ministério Público do Estado de Minas Gerais, o Compromisso de Ajustamento de Conduta envolvendo hipóteses configuradoras de improbidade administrativa (definidas na Lei n. ${ }^{\circ}$ 8.429, de 2 de junho de 1992). Disponível em:

https://www.mpmg.mp.br/files/diariooficial/DO-20171129.PDF. Acesso em: 10 jan. 2020.

OLIVEIRA, Marcelo Henrique Matos. Considerações sobre os direitos transindividuais. Cognitio Juris, João Pessoa, Ano I, Número 2, agosto 2011. Disponível em: https://www.cognitiojuris.com/artigos/02/06.html. Acesso em: 22 jan. 2020.

PAZZAGLINI FILHO, Marino. Lei de improbidade administrativa comentada: aspectos constitucionais, administrativos, civis, criminais, processuais e de responsabilidade fiscal. 7. ed. São Paulo: Atlas, 2018. 
PINHO, Humberto Dalla Bernardina de. Acordos em litígios coletivos: limites e Possibilidades do Consenso em direitos transindividuais após oadvento do CPC/2015 e da Lei de Mediação. Revista Eletrônica de Direito Processual - REDP, Rio de Janeiro, a. 12,v. 19, n. 2, maio a agosto de 2018. Disponível em: https://www.epublicacoes.uerj.br/index.php/redp/article/view/36485. Acesso em: 22 jan. 2020.

RODRIGUES, Geisa de Assis. Ação civil pública e termo de ajustamento de conduta: teoria e prática. 3. ed. Rio de Janeiro: Forense, 2011. 